YAK 347.78

DOI https://doi.org/10.32837/chc.v0i37.356

\author{
Кочина Олександра Сергївна, \\ канАиАат ЮриАичних наук, \\ Аоцент кафедри цивільного, господарського права та процесу \\ Навчально-наукового інституту права і соціальних технологій \\ Чернігівського національного технологічного університету \\ ORCID https://orcid.org/0000-0001-5625-8703
}

\title{
МІЖНАРОДНО-ПРАВОВИЙ ДОСВІД ЗАХИСТУ АВТОРСЬКИХ ПРАВ У ВСЕСВІТНІЙ IНТЕРНЕТ-МЕРЕЖІ ТА ПЕРСПЕКТИВИ ЙОГО ЗАСТОСУВАННЯ В УКРАЇНІ
}

Постановка проблеми. Вивчення питань теорії і практики мі'жнародної охорони та захисту авторських прав віА порушень у мережі Інтернет віАіграє дуже важливу роль у нинішньому світі економічного розвитку суспільства, коли відбувається поступовий рух віА матеріального виробництва Ао оперування інформацією. Інтернет став новою революційною технологією і оАночасно універсальним простором вільної комунікації, принципи організації якого заклали основи побудови нового інформаційного суспільства. Будучи наАзвичайно привабливим Аля користувачів, інтернет став площею Аля порушень авторських прав.

Інтернет $€$ глобальною і унікальною Аецентралізованою структурою, тому будь-яка спроба правового регулювання мережі стикається 3 необхінністю врахування ії екстериторіального характеру. Ця обставина змушує розробляти спеціальні піАходи Ао правового регулювання віАносин у глобальній мережі, включаючи і питання інтелектуального права.

Складність регулювання відносин в мережі Інтернет пов'язана, як вказує Ф.Ф. Гайсин, з тим, що нині ні в одній державі світу немає законів про регулювання правовіАносин у глобальній мережі, що забезпечує досить широкі можливості користувачам Аля безконтрольного віАтворення, копіювання та подальшого поширення об'єктів права. Інтернет практично не можливо обмежити рамками закону: спочатку Аумок про регулювання Аіяльності в мережі, яка самостійно розвивається, ні у кого просто не було [1, с. 51].
Стан досліАження теми. Значну кількість праць у сфері охорони інтелектуальних прав сфокусовано на дослідження різних аспектів, пов'язаних із забезпеченням правової охорони авторських прав на твори, розміщені в мережі Інтернет. СереА останніх досліАжень у вказаній сфері варто звернути увагу на Аисертаційну роботу К.О. Зерова на тему: "Особливості захисту авторських прав на твори, розміщені в мережі Інтернет" 2018 року. В роботі розглядаються аспекти міжнародного захисту авторських прав у мережі Інтернет, але комплексно це питання не розкривається. Сфера охорони авторських прав у мережі Інтернет розвивається Аосить Аинамічно, приймаються нові міжнародні нормативно-правові документи, тому вивчення міжнародно-правового досвіду захисту авторських прав у всесвітній Інтернет-мережі з метою його запровадження у вітчизняне законодавство не втрачає своєї актуальності.

Мета стапті. Метою цієї статті $є$ аналіз сучасного стану міжнародно-правового регулювання захисту авторських прав у мережі Інтернет в перспективі його впровадження у законодавство України.

ВикиаА основного матеріалу АосліАЖення 3 повним обґрунтуванням отриманих наукових результатів. СереА рейтингу країн світу, які найкраще захищають інтелектуальні права, США вважаються найпрогресивнішою країною. У зв'язку з цим їх законодавство дуже часто слугує основою Аля розробки механізмів захисту авторських прав в інших країнах. Україна не стала виключенням. 
США були першими в світі, які на законодавчому рівні врегулювали авторсько-правові віАносини у цифровому середовищі, прийнявши 12 жовтня 1998 року «Закон про авторське право у цифрову епоху" (DMCA - Digital Millennium Copyright Act) [2].

DMCA - це закон про авторське право США, який був прийнятий Сенатом Сполучених Штатів оАноголосно і піАписаний президентом Бімлом КАінтоном 28 жовтня 1998 року. Цезакон був прийнятий Аля реалізації Аоговору ВОІВ Про авторське право віА 20 грудня 1996 року та Аоговору ВОІВ Про виконання і фонограми віА тієї ж дати.

DMCA вк^ючає п'ять частин: 1. Закон про імплементацію Аоговорів ВОІВ Про захист авторських прав та Про виконання і фонограми, в якому втілені основні положенні зазначених договорів BOІВ. 2. Закон про обмеження відповідальності за порушення авторських прав в інтернеті: створює безпечну гавань Аля інтернет-провайдерів, яка полягає у звільненні їх віА відповідальності за порушення авторських прав, за умови Аотримання необхідних вимог. 3. Закон про забезпечення конкуренції у сфері технічного обслуговування комп'ютерів: передбачає виняток щодо копіювання комп'ютерних програми Аля обслуговування або ремонту комп'ютерної техніки. 4. Різні положення, в яких Аоповнені та уточнені обов'язки колективних управлінь авторськими правами; встановлені винятки у сфері застосування Закону про авторські права Аля бібліотек, Аодано положення у сфері Аистанційної освіти, положення, які стосуються колективних переговорів у разі передачі прав на кіно тощо. 5.Закон про захист конструкції судна: створює нову форму захисту А^я конструкції корпусів суден, а саме передбачає, що Аизайн корпусів суден не охоплюється законодавством про авторське право.

ОАним із основних принципів DMCA $€$ забезпечення так званої "безпечної гавані" Аля постачальників онлайн-послуг. Безпечна гавань ("safe harbors") - це чітко змальований набір обставин чи Аій в рамках конкретного закону, який звільняє віА віАповіАальності. Тобто, закон передбачає можливість власникам авторських прав віАправляти онлайн-провайдерам заяви (“DMCA takedowns"), в яких вони можуть вимагати видамити розміщений із порушенням авторських прав контент. Якщо постачальник онлайн-послуг відповідає на повідомлення про демонтаж у найкоротший термін, то він звільняється віА відповідальності за розміщення інформації з порушенням авторських прав [3].
Таким чином DMCA забезпечує піАвищений захист власників матеріалів, захищених авторським правом, одночасно обмежуючи віАповідальність постачальників онлайн-послуг. Схожий принцип знайшов втілення і в Аирективі 2001/29/ЄС Європейського парламенту та РаАи Європейського Союзу "Про гармонізацію Аеяких аспектів авторського права і суміжних прав в інформаційному суспільстві" (Аалі - Аиректива 2001/29/€C) [4].

Аиректива 2001/29/€С були прийнята 22 травня 2001 року (на Ава з половиною років пізніше, ніж Закон США про авторське право в цифрову епоху) в цілях реалізації Аоговору ВОІВ з авторського права та гармонізації різних аспектів авторського права по всій Європі, в тому числі обмежень і винятків у галузі авторського права. Аиректива була предметом безпрецелентного мобіювання і стала великим успіхом Аля авторсько-правових організацій.

СереА найважливіших положень Аирективи 2001/29/€С є ст. 6, яка вимагає віА держав-членів забезпечення "належного правового захисту" проти навмисного обходу “ефективних технологічних заходів", покликаних запобігти або обмежити акти копіювання без дозволу власників авторського права, суміжного права або права sui generis, які знаходяться в спеціальній базі даних. Стаття 8 зобов'язала держав-членів передбачити належні санкції та засоби правового захисту за порушення прав та обов'язків, визначених у цій Аирективі. Крім того, вони також повинні вживати всіх необхінних заходів Аля забезпечення застосування таких санкцій і засобів правового захисту. Аналіз Аирективи 2001/29/€С свіАчить, що нею передбачені більш м'які правила, ніж ті, що містяться в Законі США про авторське право у цифрову епоху. Крім того, в DMSA чітко прописана процедура захисту авторських прав при виявленні незаконно розміщеного контенту в інтернеті.

Що стосується України, то вітчизняне законоАавство у вказаній сфері було сформовано, спираючись на АосвіА США та ЄС. КиАається в очі той факт, що в нашій державі віАносини з захисту авторських прав у мережі Інтернет були врегульовані на рівні закону мише в 2017 році, тобто практично на 20 років пізніше, ніж це зробили США. Так, 23 березня 2017 року був прийнятий Закон України «Про державну підтримку кінематографії в Україні" [5], яким були внесені зміни до Аіючого Закону "Про авторське право і суміжні права" віА 23 грудня 1993 року [6]. 
В результаті Закон «Про авторське право і суміжні права" був доповнений низкою нових термінів ("вебсайт", "вебсторінка", "власник вебсайту", "власник вебсторінки", "гіперпосилання", "електронна (цифрова) інформація", "обліковий запис", "постачальник послуг хостингу") та ст.ст. 51-1, 51-2, якими врегульовано порядок припинення порушень авторського права з використанням мережі Інтернет. Крім того, Кодекс України про аАміністративні правопорушення був Аоповнений ст. 164-17, якою передбачена віАповіАальність постачальників послуг хостингу та власників вебсайтів за порушення умов і правил, які визначають порядок припинення порушень авторського права і (або) суміжних прав з використанням мережі Інтернет [7].

Особливої уваги заслуговує питання підстав звільнення власників вебсайту, вебсторінки та постачальників послуг хостингу віА віАповіАальності. Так, ч. 15 ст. 52-1 Закону України «Про авторське право і суміжні права" передбачає, що власник вебсайту, вебсторінки не несе віАповідальності, якщо він невідклаАно, не пізніше 48 годин 3 моменту отримання заяви про припинення порушення, унеможливив Аоступ АО електронної (цифрової) інформації, щодо якої подано заяву, та надав заявнику і постачальнику послуг хостингу інформацію про вжиті заходи. Щодо постачальників послуг хостингу, то в силу ст. 52-2 Закону № 3792-ХІІ вони звільняються віА віАповіАальності, якщо протягом 24 годин 3 моменту отримання заяви про порушення авторського права вони віАправлять власнику вебсайту її копію.

Така практика цілком віАповіАає ч. 1 ст. 247 Угоди про асоціацію України з ЄС, якою переАбачено, що постачальник послуги не несе віАповідальності за інформацію, яка зберігається на вимогу одержувача послуги, за умови, що: а) постачальнику фактично не відомо про незаконну Аіяльність або інформацію, а щодо позову про віАшкодування збитків йому не віАомо про факти або обставини, з яких випливає незаконна Аіяльність або інформація; б) постачальник після одержання таких відомостей діє оперативно, щоб зняти або зробити не можливим Аоступ до інформації [8].

Законодавство ЄС вже просунулося набагато впереА у сфері захисту авторських прав віА інтернет-порушень. Так, 17 квітня 2019 року була прийнята Аиректива 2019/79/€С про авторські та суміжні права на єАиному цифровому ринку та про внесення змін Ао Аиректив 96/9/€С та 2001/29//ЄС (Аалі - Аиректива 2019/79/ЄС) [9]. Аиректива призначена Аля обмеження поширення контенту, захищеного авторським правом, на вебплатформах.

Стаття 17 Аирективи 2019/79/€С є найбільш спірною нормою, прийнятою в парламенті $€ С$ останніми роками. Нею передбачено, що інтернет-платформи Аля обміну контентом (такі як YouTube, Vimeo) можуть бути притягнуті Ао віАповіАальності за публічне надання контенту, який порушує авторські права, навіть якщо він був завантажений їх користувачами. Такий піАхіА $\epsilon$ безпрецеАентним зрушенням у сфері віАповіАальності за порушення авторських прав платформами обміну контентом.

Ця стаття стала преАметом активних обговорень. На користь Аирективи 2019/79/ЄС виступали галузеві органи, які преАставляли виробників контенту. 84 європейський музичних та медіа-організацій, включаючи Universal Music Group i Waner Music Group, публічно заявили про піАтримку Аирективи. Інша сторона включала Аосить впливову групу критиків, Ао складу якої входили Google, Facebook, eBay, Amazon i Netflix. Вони стверджували, що прийняття цієї статті зробить майже не можливим завантаження навіть найарібнішої частини роботи, захищеної авторським правом, у Facebook, YouTube чи будь-який інший сайт. YouTube став найбільш голосним супротивником такого нововведення [10]. Але, незважаючи на Аосить аргументовані позиції проти, Аиректива 2019/79/ЄС була прийнята.

Розробники Аирективи 2019/79/ЄС вважають, що модель "notice and takedown" («повідомлення та вилучення"), яка передбачена Аирективою 2001/29/ЄС, застосовувалася Аосить непослідовно між країнами ЄС і була менш суворою, ніж аналогічні правила в Сполучених Штатах. У свою чергу основна мета ст. 17 полягає у скороченні кількості неавторизованих матеріалів, захищених авторським правом, доступних в інтернеті. Це тягне за собою вимогу Ао платформ Аля обміну контентом отримувати дозвіл віА правовласника, наприклаА у формі ліцензії, переА тим, як захищений авторським правом матеріал, завантажений його користувачами, з'явиться в публічному Аоступі [11].

СліА наголосити, що ці правила стосуються лише "online content-sharing service providers" ("платформ обміну контентом"), піА якими згіАно ст. 2 Аирективи 2019/79/ЄС необхідно розуміти постачальника послуг інформаційного суспільства, основною або однією $з$ основних цілей 
якого є зберігання та надання публічного Аоступу до великої кількості захищених авторським правом творів або інших захищених об'єктів, завантажених своїми користувачами, який він організовує і просуває в комерційних цілях.

Важливим моментом є те, що ст. 17 Аирективи 2019/79/€С передбачає і випаАки звільнення віА відповіда^ьності. Якщо платформа обміну контентом відображає захищений авторським правом матеріал без міцензії, то Аля звільнення віА віАповідальності вона повинна продемонструвати, що вона: а) Аоклала усіх зусиль Аля отримання ліцензії; б) Аоклала усіх зусиль, щоб не відображати будь-який захищений авторським правом контент, який був зареєстрований на платформі правовласником; в) прийнято рішення про негайне вилучення будь-якого захищеного авторським правом контенту після отримання повіАомлення віА Аійсного правовласника; г) доклала усіх зусиль, щоб запобігти повторному завантаженню знятого контенту.

Що стосується механізму реалізації цих правил, то передбачається, що платформи Аля обміну контентом повинні будуть використовувати автоматизовану систему, яка буде сканувати кожен вхіАний елемент контенту, щоб віАфільтрувати матеріали, захищені авторським правом. Аеякі великі платформи Аля обміну контентом вже роблять це. НаприклаА, програма ілентифікації контенту YouTube Аозволяє правовласникам реєструвати захищений авторським правом контент на YouTube, щоб можна було сканувати завантажений користувачем матеріал.

Незважаючи на те, що Аиректива 2019/79/ ЄС була прийнята 17 квітня 2019 року, в інтернет-платформ є час Аля піАготовки до 7 червня 2021 року, перш ніж прийняті правила увійдуть у національні законодавства європейських країн. Таким чином, віАчути ефективність оновленого законодавства ЄС у сфері захисту авторських прав віА інтернет-порушень нині не можливо, але його можна вважати найсучаснішим у світі.

Висновки 3 Аослідження та перспективи подальших розвіАок у цьому напрямі. В результаті проведеного АосліАження можна стверАжувати, що існуючий в Україні порядок захисту авторських прав віА порушень в мережі Інтернет був розроблений, враховуючи АосвіА США та ЄС.

Вважаю, що Україна повинна врахувати останні нововведення, запроваджені Аирективою 2019/79/ЄС, та передбачити сереА завдань Національної стратегії розвитку сфери інтелектуальної власності в Україні на період 2020-2025 рр. (нині залишається не затверАженою) продовження процесу адаптації законодавства в сфері захисту авторських прав віА порушень з використанням мережі Інтернет Ао законодавства ЄC, взявши курс на посилення відповідальності інтернет-платформ 3 обміну інформацією за публічне надання контенту, який порушує авторські права, завантаженого їх користувачами.

\section{NITEPATYPA:}

1. Гайсин Ф.Ф. Проблема нарушения авторских прав в сети Интернет. Вестник Марийского государственного университета. Серия «Исторические науки. Юридические науки». 2017. Т. 3. № 2 (10). С. 50-53.

2. The digital millennium copyright act of 1998 U.S. Copyright office summary. URL: https://www.copyright.gov/legislation/dmca. pdf.

3. Klemchuk D. DMCA Compliance. 2018. URL: https://www.klemchuk.com/dmca-compliance-requirements.

4. Директива 2001/29/ЄС Європейського парламенту та Ради Європейського Союзу «Про гармонізацію деяких аспектів авторського права і суміжних прав в інформаційному суспільстві». URL: https://zakon.rada.gov.ua/.

5. Про державну підтримку кінематографії в Україні : Закон України 23 березня 2017 року № 1977-VIII // Bidомості Bepховної Ради України. 2017. № 20. Ст. 240.

6. Про авторське право і суміжні права : Закон України від 23 грудня 1993 року № 3792-XII // Відомості Верховної Ради Украӥни. 1994. № 13. Ст. 64.

7. Кодекс України про адміністративні правопорушення від 7 грудня 1984 року № 8073-Х // Вiдомості Верховної Ради України. 1984. Дод. № 51. Ст. 1122.

8. Угода про асоціацію між Україною та Європейським Союзом, Свропейським співтовариством з атомної енергії і їхніми державами-членами від 30 листопада 2015 року. URL: https://www.kmu.gov.ua/en/yevropejska-integraciya/ugoda-pro-asociacyu.

9. Directive (EU) 2019/790 of the European Parliament and of the Council of 17 April 2019 on copyright and related rights in the Digital Single Market and amending Directives 96/9/EC and 2001/29/EC. URL: https://eur-lex.europa.eu/eli/dir/2019/790/oj.

10. What is Article 13? The EU's divisive new copyright plan explained. URL: https://www.wired.co.uk/article/what-is-article-13article-11-european-directive-on-copyright-explained-meme-ban.

11. Complying With Article 17 of the EU Copyright Directive. URL: https://www.termsfeed.com/blog/eu-copyright-directivearticle-17/. 


\section{Кочина Олександра Сергіївна \\ МІЖНАРОАНО-ПРАВОВИЙ АОСВІА ЗАХИСТУ АВТОРСЬКИХ ПРАВ У ВСЕСВІТНІЙ ІНТЕРНЕТ-МЕРЕЖІ ТА ПЕРСПЕКТИВИ ЙОГО ЗАСТОСУВАННЯ В УКРАЇНІ}

Наукова стаття присвячена АосліАженню сучасного стану міжнародно-правового регулювання захисту авторських прав в Інтернет-мережі у перспективі його впровадження у законодавство України.

Проаналізовано Закон США про авторське право у цифрову епоху (DMCA) віА 12 жовтня 1998 року, який вважається першим у світі нормативно-правовим актом з регулювання авторсько-правових віАносин у цифровому середовищі. ОАним із основних принципів DMCA є забезпечення так званої “безпечної гавані" Аля постачальників онлайн-послуг, яка полягає в тому, що постачальник онлайн-послуг звільняється віА відповіАальності за розміщення інформації з порушенням авторських прав, якщо відповіАає на заяву про видалення розміщеного 3 порушенням авторських прав контенту в найкоротший строк.

Встановлено, що схожий принцип знайшов втілення і в Аирективі 2001/29/€С Про гармонізацію Аеяких аспектів авторського права і суміжних прав в інформаційному суспільстві. Україна, спираючись на АосвіА США та $€ C$, законодавчо закріпила порядок припинення порушень авторського права з використанням мережі Інтернет мише в 2017 році.

Автор зазначає, що найважливіше значення Аля боротьби з порушеннями авторських прав в інтернеті має Аиректива 2019/79/€С Про авторські та суміжні права на єАиному цифровому ринку. Найбільший резонанс у суспільстві викликала норма ст. 17 зазначеної Аирективи, якою передбачена можливість притягнення до віАповіАальності інтернет-платформи Аля обміну контентом (такі як YouTube, Vimeо тощо) за публічне надання контенту, який порушує авторські права, навіть якщо він був завантажений їх користувачами. Такий підхіА є безпрецедентним зрушенням у сфері відповідальності за порушення авторських прав в інтернет-просторі.

3 метою запровадження європейського Аосвіду обґрунтовано необхідність продовження процесу аАаптації українського законодавства в сфері захисту авторських прав до законодавства ЄС, взявши курс на посилення віАповідальності інтернет-платформ обміну інформацією за публічне надання контенту, який порушує авторські права, завантаженого їх користувачами.

Киючові слова: авторське право, інтернет, DMSA, платформи обміну контентом, охорона та захист прав, звільнення віА віАповіАальності.

\section{Kochyna Oleksandra \\ INTERNATIONAL LEGAL EXPERIENCE OF COPYRIGHT PROTECTION IN THE WORLD INTERNET NETWORK AND THE PROSPECTS OF ITS APPLICATION IN UKRAINE}

The scientific article is devoted to the study of the current state of international legal regulation of copyright protection in the Internet network in the perspective of its implementation in the legislation of Ukraine.

The Digital Millennium Copyright Act (DMCA) of October 12, 1998, considered the world's first digital copyright regulation, has been analyzed. One of the basic principles of the DMCA is to provide a so-called "safe haven" for online service providers, which is to release the online service provider from liability for copyright infringement if it responds to a copyright infringement request. the right content as soon as possible.

It is found that a similar principle was found in Directive 2001/29/EC on the harmonization of certain aspects of copyright and related rights in the information society. Ukraine, based on the experience of the US and the EU, legislated the procedure for ending copyright infringement using the Internet only in 2017.

The author points out that Directive 2019/79/EC on copyright and related rights in the digital single market is of paramount importance for combating copyright infringement on the Internet. The greatest resonance in society caused the norm of Art. 17 of the said Directive, which provides for the possibility of liability for an online content exchange platform (such as YouTube, Vimeo, etc.) for the public disclosure of infringing content, even if it has been downloaded by their users. This approach is an unprecedented shift in online copyright liability.

In order to introduce European experience, the necessity to continue the process of adaptation of Ukrainian copyright law to EU law has been substantiated, taking the course of strengthening the responsibility of Internet platforms for the exchange of information for infringement of copyright, uploaded by their users.

Key words: copyright, internet, DMSA, content sharing platforms, protection and protection of rights, discharge. 